\title{
Influence of phosphate fertilization on phosphorus levels in foliage and tuber yield of the potato $\mathrm{cv}$. Ágata
}

\author{
Influência da adubação fosfatada no teor foliar de fósforo e na \\ produtividade de tubérculos de batata, cv. Ágata
}

\author{
José Magno Queiroz Luz ${ }^{1 *}$; Angelica Araujo Queiroz ${ }^{2}$; Marcela Borges ${ }^{3}$; \\ Roberta Camargos Oliveira ${ }^{3}$; Samara Soares Leite ${ }^{4}$; Rodrigo Ribeiro Cardoso ${ }^{4}$
}

\begin{abstract}
The healthy development of potato tubers requires, among other agricultural practices, proper fertilization. Potato crops require large amounts of nutrients, and therefore consume a large amount of fertilizer. In Brazilian soils, phosphorus is the nutrient that produces the highest response in tuber yields. The objective of this work was to study the effect of different levels of phosphorus fertilizer on the potato cultivar Ágata, by evaluating foliar levels of phosphorus and tuber yield under field conditions. The experiment was conducted at the Experimental Station of the Agriculture Cooperative Alto Paranaíba (COOPADAP) in Rio Paranaiba, Minas Gerais, during the 2008/2009 growing season. Treatments consisted of five doses of phosphorus $\left(\mathrm{P}_{2} \mathrm{O}_{5}\right)\left(0,200,400,600\right.$, and $\left.800 \mathrm{~kg} \mathrm{ha}^{-1}\right)$, with superphosphate as the source. The phosphorus content in the leaves of potato plants decreased with increasing doses of phosphorus in the soil. The crop showed an increase in tuber productivity with increasing doses of phosphorus, reaching a maximum estimated productivity of $49.11 \mathrm{t} \mathrm{ha}^{-1}$ with the application of approximately $700 \mathrm{~kg} \mathrm{ha}^{-1} \mathrm{P}_{2} \mathrm{O}_{5}$.
\end{abstract}

Key words: Solanum tuberosum L., phosphorus, mineral nutrition

\section{Resumo}

O bom desenvolvimento dos tubérculos de batata requer, entre outras práticas culturais, uma adubação adequada. A cultura da batata é altamente exigente em nutrientes, sendo responsável por um elevado consumo de fertilizantes. $\mathrm{O}$ fósforo é o nutriente que oferece maior resposta em produtividade de tubérculos nos solos brasileiros. O objetivo deste trabalho foi estudar o efeito de doses de adubação fosfatada na cultura da batata, cultivar Ágata, avaliando-se o teor foliar e a produtividade de tubérculos, em condições de campo. O experimento foi conduzido na Estação Experimental da Cooperativa Agropecuária do Alto Paranaíba - COOPADAP, localizada no município de Rio Paranaíba - MG, durante o ano agrícola de 2008/2009. Os tratamentos consistiram de cinco doses de fósforo $\left(\mathrm{P}_{2} \mathrm{O}_{5}\right)-0$, $200,400,600$ e $800 \mathrm{~kg} \mathrm{ha}^{-1}$, tendo o superfosfato simples como fonte. $\mathrm{O}$ teor de fósforo foliar nas plantas de batata diminui com o aumento das doses de adubação fosfatada. A cultura apresenta incremento de produtividade com a adição de doses crescentes de fósforo, atingido a produtividade máxima total estimada de 49,11 tha-1 com a aplicação de aproximadamente $700 \mathrm{~kg} \mathrm{ha}^{-1}$ de $\mathrm{P}_{2} \mathrm{O}_{5}$.

Palavras-chave: Solanum tuberosum L., fósforo, nutrição mineral

1 Prof. Dr., Universidade Federal de Uberlândia, UFU, Uberlândia, MG. E-mail:jmagno@umuarama.ufu.br

2 Prof $^{\mathrm{a}} \mathrm{Dr}^{\mathrm{a}}$, Instituto Federal do Triangulo Mineiro, IFTM, campus Uberlândia, MG. E-mail: angelica@iftm.edu.br

3 Discente(s) de Mestrado em Agronomia/Fitotecnia, UFU, Uberlândia, MG. E-mail: marcelabrgs@hotmail.com; robertacamargoss@gmail.com

${ }^{4}$ Eng $^{\text {'s }}$ Agr $^{\text {'s }}$, UFU, Uberlândia, MG. E-mail: samarasleite@yahoo.com.br; rrodrigo_rc@yahoo.com.br

* Author for correspondence 


\section{Introduction}

The potato (Solanum tuberosum L.) is an increasingly important source of food, income, and rural employment in Brazil, potentially contributing to the social stabilization of the rural environment (PEREIRA; DANIELS, 2003). It ranks third among the most consumed foods in the world (STUMPF JUNIOR, 2011), being cultivated in more than 125 countries (FAO, 2009).

Three hundred and twenty million tons of potatoes are produced annually on 19.3 million hectares, which makes the potato a potentially important food source for eradicating hunger throughout the world (AGRIANUAL, 2011). The main potato-producing states in Brazil are Minas Gerais, São Paulo, Paraná, Santa Catarina, Rio Grande do Sul, Goiás, and Bahia (ABBA, 2007).

The high productivity of this crop is a result of the technological advances adopted by the food producers, particularly in relation to irrigation use and management, quality of potato seed, blight/ diseases control, and fertilization (MAROUELLI; GUIMARÃES, 2006). Moreover, the potato crop uses the highest amounts of fertilizers, resulting in increased costs to the growers. Comparing the costs of potatoes planted from August to December and soy cultivated during the same period, it was observed that the cost of this insume, fertilizer is up to 7.2 times higher than when it is used for soy (AGRIANUAL, 2011).

The nutrients extracted by different potato cultivars are, in decreasing order, potassium $(\mathrm{K})$, nitrogen $(\mathrm{N})$, calcium $(\mathrm{Ca})$, phosphorus $(\mathrm{P})$, magnesium $(\mathrm{Mg})$, sulfur $(\mathrm{S})$, iron $(\mathrm{Fe})$, manganese $(\mathrm{Mn})$, zinc $(\mathrm{Zn})$, copper $(\mathrm{Cu})$, and boron $(\mathrm{B})$ (FERNANDES, 2010). P, in spite of not being the most absorbed nutrient, offers the highest response in tuber productivity in Brazilian soils (FILGUEIRA, 2008); therefore, it deserves special attention. This response in productivity can be attributed to the fact that $\mathrm{P}$ is present in different phases of the plant's metabolism. It is part of DNA,
mRNA, ATP, and phospholipid structures in the cell membranes. It is also involved in biosynthesis and energy transference reactions, and affects the functional properties of the starch in which it is present (SUBRAMANIAN et al., 2011).

$\mathrm{P}$ is an element that is least available in the soil. Its concentration in soil solution is usually low, which makes absorption by the plant's roots more difficult and, consequently, reduces the expression of the genetic potential of the plants in terms of development and productivity (HAMMOND et al., 2009). This occurs particularly in acid soils, such as the ones found in Cerrado, in which $\mathrm{P}$ rapidly forms insoluble complexes with cations $\mathrm{Al}$ and $\mathrm{Fe}$, which are widely encountered in this soil (VANCE; STONE; ALLAN, 2003). Furthermore, potato plants have difficulty assimilating $\mathrm{P}$, making the presence of the element in the soil indispensable with an easily capable of being placed source and in sufficient quantity (MALLMANN, 2001); however, the amount being applied must be carefully calculated to maintain a balance between productivity and environmental and production costs.

In addition to increasing production costs, excessive doses of $\mathrm{P}$ might contaminate superficial waters. This was observed by White and Hammond (2009), who reported habitat losses and biodiversity reduction in superficial waters that contained high amounts of nutrients that originated from soil erosion and superficial drainage.

The aim of this study was to evaluate the effect of $\mathrm{P}$ fertilization on the $\mathrm{P}$ content in the potato leaf, tuber productivity, and its availability in the soil after harvest.

\section{Material and Methods}

The experiment was carried out at the Experimental Station of Agriculture Cooperative Alto Paranaíba (COOPADAP) in Rio Paranaiba, Minas Gerais, during the 2008/2009 growing season. The soil of the experimental area was 
classified as Oxsoil (EMBRAPA, 2006), with a clay texture and the following chemical characteristics in the 0- to 0.2-m layer: $\mathrm{pH}=5.0, \mathrm{P}$ Mehlich $=25$ $\mathrm{mg} \mathrm{dm}{ }^{-3}, \mathrm{~K}=0.29 \mathrm{cmol}_{\mathrm{c}} \mathrm{dm}^{-3}, \mathrm{Ca}=4.5 \mathrm{cmol}_{\mathrm{c}} \mathrm{dm}^{-}$ 3, $\mathrm{Mg}=0.8 \mathrm{cmol}_{\mathrm{c}} \mathrm{dm}^{-3}, \mathrm{Al}=0.1 \mathrm{cmol}_{\mathrm{c}} \mathrm{dm}^{-3}, \mathrm{H}+$ $\mathrm{Al}=5.3 \mathrm{cmol}_{\mathrm{c}} \mathrm{dm}^{-3}, \mathrm{SB}=5.6 \mathrm{cmol}_{\mathrm{c}} \mathrm{dm}^{-3}$, cation exchange capacity $(\mathrm{CEC})=10.9 \mathrm{cmol}_{\mathrm{c}} \mathrm{dm}^{-3}, \mathrm{M} . \mathrm{O}=$ $0.8 \%$, Base Saturation $(\mathrm{V})=51 \%, \mathrm{~S}=18 \mathrm{mg} \mathrm{dm}^{-}$ ${ }^{3}, \mathrm{~B}=0.28 \mathrm{mg} \mathrm{dm}^{-3}, \mathrm{Cu}=0.6 \mathrm{mg} \mathrm{dm}^{-3}, \mathrm{Fe}=51.0$ $\mathrm{mg} \mathrm{dm}{ }^{-3}, \mathrm{Mn}=14.5 \mathrm{mg} \mathrm{dm}^{-3}$, and $\mathrm{Zn}=12.5 \mathrm{mg}$ $\mathrm{dm}^{-3}$. Ca, $\mathrm{Mg}$, and changeable $\mathrm{Al}$ were extracted with $1 \mathrm{~mol} \mathrm{~L}^{-1} \mathrm{KCl}$; available $\mathrm{P}$ and $\mathrm{K}$ with 0.05 mol L-1 $\mathrm{HCl}+0.025 \mathrm{~mol} \mathrm{~L}^{-1} \mathrm{H}_{2} \mathrm{SO}_{4} ; \mathrm{H}+\mathrm{Al}$ with SMP; and MO, making use of the Walkley-Black method, following the Minas Gerais Soil Fertility Commission (CFSMG, 1999).

Randomized blocks with four repetitions were used for the experiment. The treatment consisted of five doses of $\mathrm{P}_{2} \mathrm{O}_{5}\left(0,200,400,600\right.$, and $\left.800 \mathrm{~kg} \mathrm{ha}^{-1}\right)$. Each experimental plot was $27 \mathrm{~m}^{2}$ and comprised six rows $6 \mathrm{~m}$ long and $0.75 \mathrm{~m}$ apart. Potato seeds were planted every $0.2 \mathrm{~m}$. A useful area corresponded to two central rows, disregarding $0.5 \mathrm{~m}$ at both ends.

Doses of $\mathrm{P}$ were applied to the soil in the planting furrow and combined with amounts of $\mathrm{N}$ and $\mathrm{K}$ recommended by CFSMG (1999) (N: $140 \mathrm{~kg} \mathrm{ha}^{-1}$, $\left.\mathrm{K}_{2} \mathrm{O}: 300 \mathrm{~kg} \mathrm{ha}^{-1}\right)$. Thirty kilograms per hectare of a mixture of $2.7 \% \mathrm{Ca}, 8.2 \% \mathrm{~S}, 12 \% \mathrm{Zn}$, and $6 \%$ $\mathrm{B}$ were also applied. The nitrogenous fertilization was divided as follows: $20 \%$ of the recommended dose was used in the furrow at planting and $80 \%$ was broadcast atop the soil with the earthing-up operation 25 days after planting. Urea ( $43 \%$ of $N$ ) provided the $\mathrm{N}$ source, simple superphosphate $(17 \%$ of $\left.\mathrm{P}_{2} \mathrm{O}_{5}\right)$ the $\mathrm{P}$ source, and potassium chloride $(57 \%$ of $\mathrm{K}_{2} \mathrm{O}$ ) the $\mathrm{K}$ source.

The experimental area was prepared following the traditional procedures of plowing deeply, disking twice, and incorporating dolomitic calcareous $(\mathrm{MgO}=16 \%, \mathrm{CaO}=33 \%$, PRNT $=85 \%)$. As with the fertilization process, lime was applied to the soil following CFSMG (1999) guidance. The V\% recommended for the potato crop was 60 . One ton per hectare of calcareous was applied 60 days before the crop was planted.

After the soil was prepared, the nutrients were manually added to the planting furrow and incorporated using a hoe. The seed potatoes of the Ágata cultivar type III (tubers with a 3- to $4-\mathrm{cm}$ maximum transversal diameter) were also manually distributed into the planting furrow. After applying the phytosanitary products for initial protection of the tubers, the furrows were covered with soil.

The phytosanitary treatment conducted throughout the development of the crop was based on data from monitoring blight and diseases, with the same treatment being used in commercial farming. The products used for the control of blight, diseases, and weeds are registered for the potato crop and were applied in the recommended doses. At 54 DAP, when the culture was in stage III (tuberization), samples of foliage were taken, collecting 20 complete leaves (limb + petiole) of the fully developed third trefoil in each part of the experiment according to the recommendation of CFSMG (1999). The leaves were evaluated for $\mathrm{N}$, $\mathrm{P}, \mathrm{K}, \mathrm{Ca}, \mathrm{Mg}, \mathrm{S}, \mathrm{B}, \mathrm{Zn}, \mathrm{Cu}$, and $\mathrm{Mn}$ according to the methods recommended by Embrapa (1999).

The harvested tubers (97 DAP) were immediately classified according to transversal diameter as follows: Type I $(>7 \mathrm{~cm}$ ), Type II (from 4.2 to 7.0 $\mathrm{cm}$ ), Type III (from 3.3 to $4.2 \mathrm{~cm})$, Type IV $(<3.3$ $\mathrm{cm}$ ) (CEAGESP, 2001), and disposal (rotten, green, nematodes, mechanical damage, etc.). The tubers were weighed using an analytical balance to measure the fresh material mass considered the useful area of each part. The productivity results were expressed in terms of production per ha. Soil samples were collected in each part to determine the $\mathrm{P}$ available in the soil using the Resin method according to CFSMG (1999).

A variance analysis was performed on the collected data. A regression analysis was performed on those data that showed a significant difference for the $\mathrm{F}$ test. 


\section{Results and Discussion}

The $\mathrm{P}$ content in the foliage statistically differed between the applied doses. The most adequate was the quadratic equation (Figure 1). The lowest estimated $\mathrm{P}$ content observed was $2.26 \mathrm{~g} \mathrm{~kg}^{-1}$ in the doses of $800 \mathrm{~kg} \mathrm{ha}^{-1}$ of $\mathrm{P}_{2} \mathrm{O}_{5}$, which means that the content of the nutrient in the tissues of the plant did not increase with a higher addition of $\mathrm{P}$ to the soil. In fact, the opposite happened: the higher the $\mathrm{P}$ doses to the soil, the less $\mathrm{P}$ there was in the foliage.

Figure 1. Leaves content of $\mathrm{P}$ in function of levels $\mathrm{P}_{2} \mathrm{O}_{5}$ added at planting furrow, cv. Ágata. Rio Paranaíba, COOPADAP/UFU, 2009.

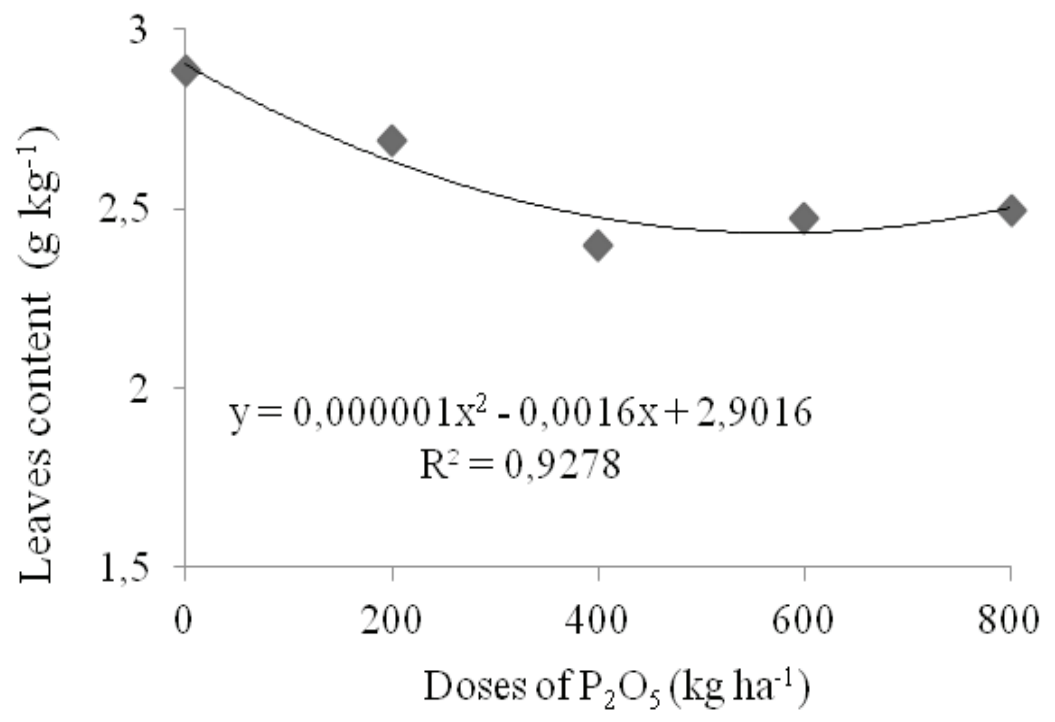

Source: Elaboration of the authors

This fact indicates that, in spite of the presence of the nutrient in the soil, the plants could not absorb it in excessive amounts and translocate it into the leaves up to the time of sampling (54 DAP).

According to CFSMG (1999), the ideal P content in potato leaves is between 2.9 and $5.0 \mathrm{~g}$ $\mathrm{kg}^{-1}$; therefore, only doses next to the control show these values $\left(0 \mathrm{~kg} \mathrm{ha}^{-1}\right.$ of $\left.\mathrm{P}_{2} \mathrm{O}_{5}\right)$ (Figure 1). This is partially explained by the fact that the sampling was carried out during the tuberization phase, in which the plant nutrients and energy were concentrated to form and fill the tubers.

Fernandes (2010) studying the nutrient accumulation and exportation in the Ágata cultivar observed that the initial accumulation of $\mathrm{P}$ found at $20 \mathrm{DAP}$ in the leaves was $7.7 \mathrm{~g} \mathrm{~kg}^{-1}$ and decreased as the phenological stage progressed. In the swab at 55 DAP, the calculated value was $3.7 \mathrm{~g} \mathrm{~kg}^{-1}$, which is much higher than all the other values found in this experiment. This accumulation in the initial period of development and its later reduction were also observed by the authors in the cultivars Asterix, Atlantic, Markies, and Mondial.

Fernandes, Soratto, and Silva (2011), studying the extraction and exportation of nutrients in the Ágata cultivar, found a P content in the leaf of 5.3 $\mathrm{g} \mathrm{kg}^{-1}$ in an analysis conducted at 48 DAP. The high content was expected due to the high level of the element present in the soil before planting and the high doses of $\mathrm{P}$ fertilizers added to the area. These authors also observed that extraction of $\mathrm{P}$ from the soil by the potato crop was small even with a high availability of the nutrient; the cultivar that absorbed 
the most $\mathrm{P}$ extracted only $6.4 \%$ of the total $\mathrm{P}$ applied to the soil.

In terms of the productivity of tubers, only Types I, II, and total productivity (which comprised Types I, II, III, IV, and disposal) presented relevant differences between distinctive doses of $\mathrm{P}_{2} \mathrm{O}_{5}$
(Figure 2). The estimated responses of Types I and II were similar, showing an increase in productivity as the doses of fertilizers were increased, while the estimated total maximum productivity $\left(49.11 \mathrm{t} \mathrm{ha}^{-1}\right)$ was obtained with the application of $693,33 \mathrm{~kg} \mathrm{ha}^{-}$ ${ }^{1}$ of $\mathrm{P}_{2} \mathrm{O}_{5}$.

Figure 2. Productivity of tubers Type I (A), II (B) and total (C), in function of $\mathrm{P}_{2} \mathrm{O}_{5}$ applied at planting furrow, cv. Ágata. Rio Paranaíba, COOPADAP/UFU, 2009.
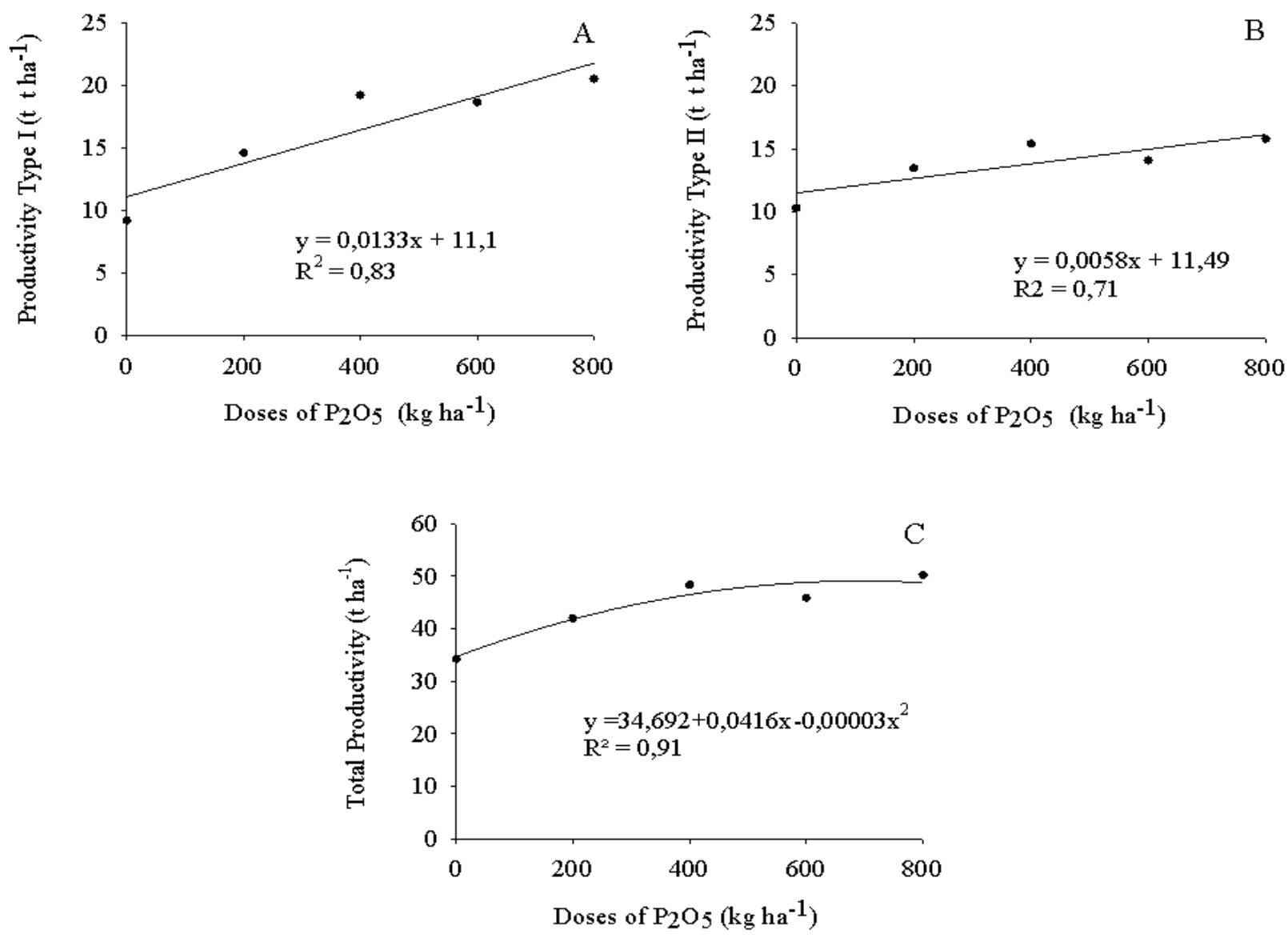

Source: Elaboration of the authors.

The increase in the production of larger tubers suggests that $\mathrm{P}$ is an important element for tuber development, maximizing the metabolic processes of the plants, such as the translocation of photoassimilates. According to Dias (1986) and Filgueira (2008), P is a key nutrient for obtaining high potato productivity, stimulating tuberization, accelerating maturation, increasing the incidence of larger tubers, and regulating production.

Fontes, Paula, and Mizubuti (1987), cultivating potatoes, also registered an increase in production 
with a higher application of $\mathrm{P}$. The authors observed that the absence, as well as the excess, of phosphorous fertilizer caused a reduction in the number of tubers per plant.

According to Fernandes (2010), who studied the increase, productivity, and exportation of nutrients in potato crops, observed that potato tubers become a major drain on plants, presenting, at the end of the cycle, between $75 \%$ and $78.5 \%$ of the total of $\mathrm{P}$ absorbed by the Ágata cultivar plants. By doing this, it is possible to obtain a tuber productivity of $37.268 \mathrm{~kg} \mathrm{ha}^{-1}$.

Moraes, Nogueira, and Alvarenga (1991), examining doses of $\mathrm{P}\left(0,200,400\right.$, and $600 \mathrm{~kg} \mathrm{ha}^{-1}$ $\mathrm{P}_{2} \mathrm{O}_{5}$ ) and gypsum in tuber production, detected an increase in the number of tubers per plant and observed maximum tuber productivity when doses of $470 \mathrm{~kg} \mathrm{ha}^{-1} \mathrm{P}_{2} \mathrm{O}_{5}$ were used; however, a reduction in weight was also reported, which demonstrated the importance of $\mathrm{P}$ as a nutrient for potatoes. Nava, Dechen, and Iuchi (2007) reported P as the most important nutrient for the increase in tuber production, with the highest productivity obtained with the doses of $690 \mathrm{~kg} \mathrm{ha}^{-1} \mathrm{P}_{2} \mathrm{O}_{5}$, with a difference of $25 \mathrm{t} \mathrm{ha}^{-1}$ in relation to the control.

Mallmann et al. (2007), in an experiment conducted with the Ágata cultivar, examined four sources of $\mathrm{P}$ (simple superphosphate, triple superphosphate, thermophosphate, and Arad reactive phosphate), using four different doses (120, 420,630 , and $840 \mathrm{~kg} \mathrm{ha}^{-1} \mathrm{P}_{2} \mathrm{O}_{5}$ ), and observed the highest tuber productivity with application of the highest doses $\left(840 \mathrm{~kg} \mathrm{ha}^{-1} \mathrm{P}_{2} \mathrm{O}_{5}\right)$.

High doses of $\mathrm{P}$, according to the aforementioned studies, and emphasized by this present study, increased tuber productivity; however, before this protocol is adopted by the food producers, it is essential to carry out an economic analysis. The price of the product as well as the fertilizer varies on the market and this might make the practice impractical.

In inadequate management of soils with a low capacity for adsorption, there is another factor to be evaluated when high levels of fertilizers are added after it is partially recovered by the crops. In these cases, the excess fertilizers in the soil solution can be removed from the soil during drainage, contaminating superficial waters. (WHITE; HAMMOND, 2009).

$\mathrm{P}$ contents in the soil after harvest, extracted using the Resin method, were influenced by the P fertilizer doses, presenting a linear behavior. This means that the higher the doses of $\mathrm{P}$ applied to the planting furrow, the higher the $\mathrm{P}$ content in the soil (Figure 3); however, there were no differences in the amount of $\mathrm{P}$ that remained in the soil, most likely because of the high capacity of $\mathrm{P}$ adsorption by the soil. The soil that is found in the area of the experiment is the same as that usually found in Cerrado and, in spite of having a clay texture, there is the predominance of sesquioxide of $\mathrm{Fe}$ and $\mathrm{Al}$, which presents a high capacity for $\mathrm{P}$ adsorption.

According to Marcolan (2006), clay soils composed mainly of oxyhydroxides of Fe and Al present a high capacity for $\mathrm{P}$ adsorption; therefore, as they present more surface exposure to new sites of adsorption, they need higher $\mathrm{P}$ doses to maintain the $\mathrm{P}$ concentration in the soil solution. Hence, although the concentration of $\mathrm{P}$ in the soil is high in relation to the amount needed for plant growth, only a small part of it is available for plants. 
Figure 3. Phosphorus available in the soil after harvest, using the Resin method. Rio Paranaíba, COOPADAP/UFU, 2009.

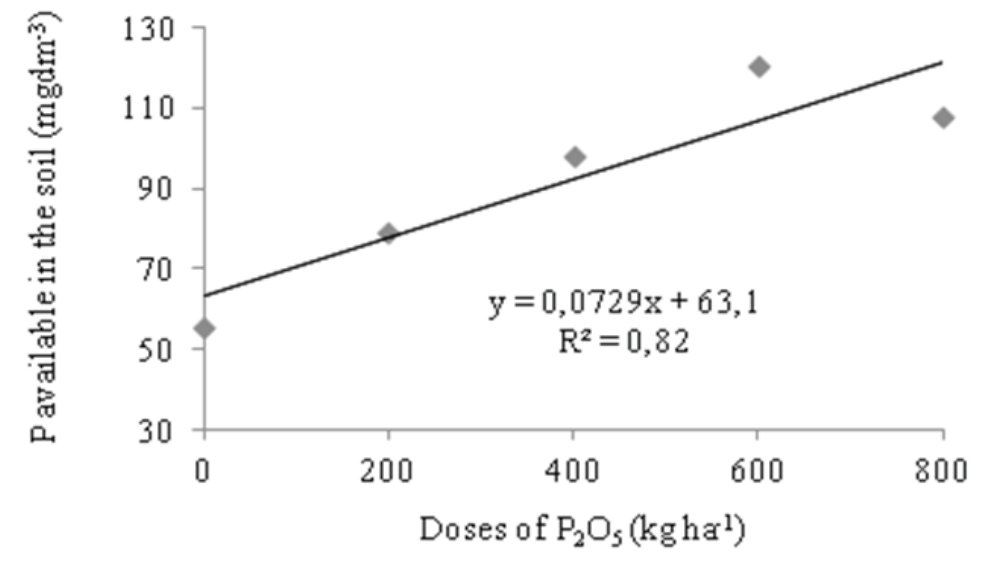

Source: Elaboration of the authors.

High amounts of fertilizers applied to the soil leave behind residues, which can positively influence the chemical characteristics of the soil, favoring the cultivation of chain crops, as it was observed by Silva, Silva Filho, and Alvarenga (2000) in a study with maize production following potato production. According to these authors, the residual efficiency of nutrients over plant productivity depends on different factors such as weather conditions, soil type, soil colloid adsorption capacity, and crop removal capacity.

\section{Conclusion}

The $\mathrm{P}$ content in the foliage of potato plants decreases with an increase in phosphate fertilization.

There is an increase in total tuber productivity until the approximate estimated dose of $700 \mathrm{~kg} \mathrm{ha}^{-1}$ $\mathrm{P}_{2} \mathrm{O}_{5}$.

\section{Credits}

We acknowledge COOPADAP in Rio Paranaiba and CREA-MG for support of the execution of this experiment.

\section{References}

ASSOCIAÇÃO BRASILEIRA DA BATATA - ABBA. Área, produção e produtividade. 2007. Disponível em: $<$ http://www.abbabatatabrasileira.com.br/images/pdf/ batatabrasil_app.pdf $>$. Acesso em: 07 fev. 2012.

ANUÁRIO DA AGRICULTURA BRASILEIRA AGRIANUAL. Batata. São Paulo: FNP, 2011. 482 p.

CEAGESP. Classificação da batata in natura. São Paulo: CEAGESP, jun. 2001. (folder).

COMISSÃO DE FERTILIDADE DO SOLO DO ESTADO DE MINAS GERAIS - CFSMG. Recomendações para o uso de corretivos e fertlizantes em Minas Gerais. 5a Aproximação. Viçosa: UFV, 1999. $176 \mathrm{p}$.

DIAS, C. A. C. Batatinha: uma cultura muito lucrativa para quem planta com cuidado. São Paulo: Ícone, 1986. $101 \mathrm{p}$.

EMPRESA BRASILEIRA DE PESQUISA AGROPECUÁRIA - EMBRAPA. Sistema brasileiro de classificação de solos. Brasília: EMBRAPA, 2006. 306 p.

Manual de análise química dos solos, plantas e fertilizantes. Rio de Janeiro: Embrapa Solos, 1999. 370 p.

FOOD AND AGRICULTURE ORGANIZATION OF THE UNITED NATIONS - FAO. FAOSTAT: Crops, dez. 2009. Disponível em: <http://www.faostat.fao.org/ site/567/DesktopDefault.aspx>. Acesso em: 20 jan. 2012. 
FERNANDES A. M. Crescimento, produtividade, acúmulo e exportação de nutrientes em cultivares de batata (Solanum tuberosum L.). 2010. Dissertação (Mestrado em Agronomia) - Faculdade de Ciências Agronômicas. Universidade Estadual Paulista, Botucatu.

FERNANDES, A. M.; SORATTO, R. P.; SILVA, B. L. Extração e exportação de nutrientes em cultivares de batata: I - macronutrientes. Revista Brasileira de Ciência do Solo, Viçosa, MG, v. 35, n. 6, p. 2039-2056, 2011.

FILGUEIRA, F. A. R. Novo manual de olericultura. Viçosa: UFV, 2008. $421 \mathrm{p}$.

FONTES, P. C. R.; PAUlA, M. B.; MIZUBUTI, A. Produtividade da batata sob influência de níveis do fertilizante 4-14-8 e do superfosfato simples. Revista Ceres, Viçosa, v. 34, n. 191, p. 90-98, 1987.

HAMMOND, J. P.; BROADLEY, M. R.; WHITE, P. J.; KING, G. J.; BOWEN, H.C.; HAYDEN, R.; MEACHAM, M. C.; MEAD, A.; OVERS, T.; SPRACKLEN, W. P.; GREENWOOD, D. J. Shoot yield drives phosphorus use efficiency in Brassica oleracea and correlates with root architecture traits. Journal of Experimental Botany, Oxford, v. 60, n. 7, p. 1953-1968, 2009.

MALLMANN, N. Efeito da adubação na produtividade, qualidade e sanidade de batata cultivada no CentroOeste paranaense. 2001. Dissertação (Mestrado em Agronomia) - Universidade Federal do Paraná, Curitiba.

MALLMANN, N.; DESCHAMPS, C.; MOGOR, Á. F.; DIAS, J. A. C. S.; CINTRA, A. P. U. Doses e fontes de fósforo na multiplicação de tubérculos de batatasemente a campo. In: ENCONTRO NACIONAL DE PRODUÇÃO E ABASTECIMENTO DE BATATA, 13., 2007, Holambra, SP. Anais... ABBA, 2007. Disponível em: <http://www.abbabatatabrasileira.com. br/batatashow4/resumos/resumo_28.pdf $>$. Acesso em: 13 ago. 2010.

MARCOLAN, A. L. Suprimento e absorção de fósforo em solos submetidos a diferentes sistemas de preparo. 2006. Tese (Doutorado em Ciência do Solo) - Universidade Federal do Rio Grande do Sul, Porto Alegre.
MAROUELLI, W. A.; GUMARÃES, T. G. Irrigação na cultura da batata. Itapetininga: Associação Brasileira da Batata, 2006. 66 p.

MORAES, C. P. A.; NOGUEIRA, F. D.; ALVARENGA, M. A. R. Efeito de diferentes níveis de fósforo e de gesso sobre algumas características morfológicas da planta da batata (Solanum tuberosum L.). Horticultura Brasileira, Brasília, v. 9, n. 1, p. 45-47, 1991.

NAVA, G.; DECHEN, A. R.; IUCHI, V. L. Produção de tubérculos de batata-semente em função das adubações nitrogenada, fosfatada e potássica. Horticultura Brasileira, Brasília, v. 25, n. 3, p. 365-370, 2007.

PEREIRA, A. S.; DANIELS, J. O cultivo da batata na região sul do Brasil. Brasília: EMBRAPA Informação Tecnológica, 2003. 567 p.

SILVA, E. C.; SILVA FILHO, A. V.; ALVARENGA, M. A. R. Efeito residual da adubação da batata sobre a produção de matéria seca e exportação de nutrientes do milho verde. Ciência e Agrotecnologia, Lavras, v. 24, n. 2, p. 509-515, 2000.

STUMPF JUNIOR, W. Produção de batata no Rio Grande do Sul. Versão Eletrônica, Embrapa, 2011. (Sistemas de Produção, 19). Disponível em: <http://www. cpact.embrapa.br/publicacoes/catalogo/tipo/sistemas/ sistema19_novo/index.htm>. Acesso em: 12 mar. 2012.

SUBRAMANIAN, N. K.; WHITE, P. J.; BROADLEY, M. R.; G. RAMSAY. The three-dimensional distribution of minerals in potato tuber. Annals of Botany, London, v. 107, n. 4, p. 681-691, 2011.

VANCE, C. P.; STONE, C. U.; ALLAN, D. L. Phosphorus acquisition and use: critical adaptations by plants for securing a nonrenewable resource. New Phytologist, London, v. 157, n. 1, p. 423-447, 2003.

WHITE, P. J.; HAMMOND, J. P. The sources of phosphorus in the waters of Great Britain. Journal of Environmental Quality, Madison, v. 38, n. 1, p. 13-26, 2009. 